\title{
Summary
}

The first administrative and police bodies of the Russian state on the territory of Ukraine were the offices of the Russian voivods departments. The appearance of the voivod on the lands of Ukraine takes place during the second half of the XVII century. Police functions of the voivod along with military, judicial and financial were the main areas of their activities.

Keywords: administrative and police bodies, department, Prikaz, Slobozhanshchina, streltsys, voivod (voivode), voivod-prikaz system, voivodship.

УДК 342.95

DOI: $10.31733 / 2078-3566-2019-3-118-122$

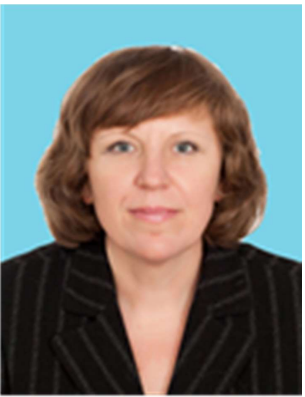
Svitlana
Iryna
TISHCHENKOVA $^{\circledR}$ TYSHCHENKOVA $^{\oplus}$
Ph.D, Prof.
Ph.D, Ass. Prof.

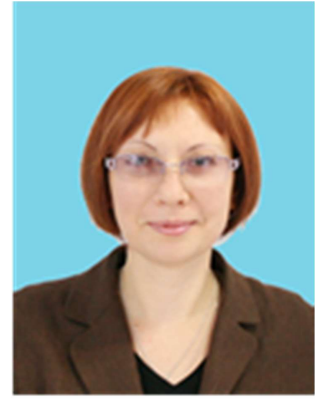

\section{TYPOLOGY OF MIGRATION IN THE CONTEXT OF UPDATING HUMAN RIGHTS AND FREEDOMS PROTECTION IN THE PRESENT-DAY WORLD}

Світлана Тіщенкова, Ірина Тищенкова. ТИПОЛОГІЗАЦІя МІГРАЦІї В КОНТЕКСТІ УДОСКОНАЛЕННЯ ЗАХИСТУ ПРАВ І СВОБОД ЛЮДИНИ В СУЧАСНОМУ

CBITI. У сучасному глобалізованому світі особливої актуальності набувають проблеми, пов'язані 3 трудовою міграцією населення як одного із визначальних чинників суспільного життя держав, що активно стимулює соціально-економічну та регуляторну діяльність їх громадських систем. Висвітлення питань ефективного управління міграційними процесами $є$ пріоритетним у сучасних наукових дослідженнях у галузі права і суспільствознавства в цілому. Відповідно набуває все більшої актуальності проблема типології міграції, оскільки однозначність в розумінні критеріїв, за якими мігрант буде віднесений до тієї чи іншої категорії, дозволить забезпечити його необхідний правовий захист і реалізацію встановлених законом прав і свобод.

В існуючих підходах практично не інтегровані нові види і форми міграцій, пов’язаних із глобалізацією світової спільноти, із розвитком новітніх інформаційних технологій. Суспільні трансформації останніх десятиліть і технічний прогрес викликають закономірні зміни і в процесах, пов'язаних із переміщенням індивідів в соціальному просторі. Йдеться про віртуальні міграції, облік яких фактично не здійснюється державними службами статистики. Хоча з позицій аналізу змін у соціумі ця категорія міграцій не менш важлива: вона трансформує звичне сприйняття соціального простору, культури і системи цінностей, змінює усталені моделі суспільної взаємодії. Таким чином, сформовані протягом тривалого періоду способи класифікації міграцій, що виражаються у традиційних формах побудови міграційної політики держав, втрачають свою колишню дослідницьку вагу, поступаючись місцем транснаціональним вимірам.

Виходячи 3 актуальності цієї проблематики, авторами статті зроблено спробу систематизувати існуючий досвід типологізації міграцій і запропонувати уніфікований підхід до використання певної типології для забезпечення правового захисту даної категорії населення.

Ключові слова: міграчія, типологізація, систематизація, критерій, захист, права і свободи.

Problem statement. In today's globalized world, linked to the challenges of transnationalization of the migration sphere, labor migration, as one of the determining factors in the social life of states, actively stimulates the social and economic and regulatory activities of

(C) Тіщенкова C.O., 2019

ORCID iD: https://orcid.org/0000-0002-0130-0422

tishchenkova@ukr.net

(c) Тищенкова I.O., 2019

ORCID iD: https://orcid.org/0000-0003-0323-5035

iren9357@gmail.com 
their social systems. In general, the cross lighting of issues related to effective management of migration processes is a priority of present-day scientific researches. In this regard, the problem of the typology of migration is becoming increasingly relevant, since the unambiguous understanding of the criteria by which a migrant will be classified in one or another category will ensure the necessary legal protection and realization of the rights and freedoms established by the law.

Analysis of the publications that started solving this issue. This problem has recently become the subject of scientific analysis of many domestic and foreign researchers, among which, first of all, V. Avliyev, V. Bidak, T. Zaslavskaya, V. Inozemtsev, V. Shvetsov V., M. Kuillin, R Maynes, P. Petsley, R. Lapper, L. Lisogor, Ravenstein, L. Rybakovsky, M. Romaniuk and others. The indicated scientists highlighted the approaches to the development of a theoretical and methodological base for studying labor migration. The essence of the phenomenon of migration, patterns, specificity and features of manifestation in various economic conditions have been properly disclosed. The issues of the formation of the migration policy of individual countries are focused on in the works of such well-known specialists in this sphere as J. Borgas, S. Drinkwater, R. Kauser, G. Crowley, H. Rust and others. Considerable attention in these works is being paid to financial, social, political and cultural aspects of migration. At the same time, insufficient attention has been paid to the typology of migration in the scientific literature, which has determined the line of our study.

Article's objective: to systematize existing experience in typologing migrations, to identify existing problematic aspects, and to offer on this basis a unified approach to the use of a particular typology to ensure the legal protection of migrants.

Basic content. There are a large number of typologies of migrations reflected in the scientific literature. They are usually based on sociological, demographic and economic approaches to the definition of migration and migration behavior. To conduct typologization, several basic criteria are used, such as orientation, time extent, method of involvement in migration behavior, causality, socio-demographic characteristics of migration subjects, and legality of border crossing. Within the framework of each typology, researchers group migration processes on the basis of isolating certain common features, trying to streamline them, create a system that could be used in further study and analysis of this phenomenon. The typologization methods that have been developed over a long period of time are expanding, supplementing, but, unfortunately, a unified approach to using a certain typology to provide legal protection for migrants has not been formed yet. Let us consider in detail the criteria that are used for existing typologies. So, in accordance with the temporary criterion, migration is divided into permanent and temporary. It should be noted that this classification is conditional and is associated with the concept of «temporality» of staying on the strange territory. In the understanding of constancy or inconstancy, one should proceed from the legal consolidation of an individual in the territory chosen by him for migration, which again returns to a legal approach to the interpretation of migration definition. Temporality does not imply «rooting» in new conditions, society. In this regard, temporary migration is considered as migration, mainly from an economic point of view. Temporary migrations are directly related to the functioning of the economic and political system in a particular region. In the framework of the concept of temporary migration, seasonal migration, associated with the seasonality of economic activity, is distinguished. The current state of seasonal migration is associated with the regional division of labor. In particular, regions with a developed tourism business are characterized by an influx of able-bodied people in the most attractive for tourists time periods. And at the same time, there is a significant outflow of labor force from the countries that are considered to be migratory donors. This leads to an imbalance in the economy and other social problems. In addition, constant seasonal migrations erode regional identity, giving it duality traits.

In addition to seasonal migrations, the category of temporary migrations includes the so-called «pendulum» migrations associated with interval flows of migrations from one point to another. Pendulum migrations include temporary labor migrations (from peripheral cities to the capital, and so on), educational migrations, and recreational migrations (treatment, rest, and so on). The migration is considered to be permanent if the individual has made a change of residence and is trying to «gain a foothold» in the new territory, while the length of staying there is a legally determined norm.

Another important criterion for classifying migration is becoming a method of involvement in migration. Here, voluntary migration, involuntary and forced migration are distinguished. Voluntary migrations are triggered by a conscious decision to move an individual 
or group of people. The migration is considered involuntary in case the complex of displacing factors acquires strong decisive importance. Such displacing factors can be military operations, environmental or technological disasters, economic and social problems. Forced migration is directly related to the administrative approach to managing migration. As a rule, forced migration is discriminatory and is aimed at a specific ethnic, religious, socio-economic group. Forced migration is directly related to the political and legal transformations of society carried out by the state policy. The most common form of forced migration is deportation.

Migrations related to forced goal-setting are divided into migration of refugees and internally displaced persons (displaced persons). A legal approach is used to highlight these categories, since it is practically impossible to establish fundamental differences from the substantive standpoint. Researchers themselves speak of a «floating» division into refugees and immigrants.

In some legal documents it is related to the category of citizenship. Nevertheless, in the legislative framework of different countries, laws on refugees and internally displaced persons actualize this type of migration. In present-day scientific works, there appear attempts to separate these two types of migrations, but there is no definite research approach so far.

Forced migrations are divided into violent and repressive. In both cases, individuals become migrants not of their own free will, but by virtue of administrative decisions or malicious intent. This, as a rule, is associated with certain discrimination on ethnic, religious, class, and sometimes gender grounds. First of all, one should turn to criminal acts that cause forced migration. What is meant here is human trafficking, slavery and illegal deprivation of freedom of movement, forced restraint of people. At first glance, in the current legal system, it seems to be an obsolete type of migration, but according to the latest UN figures, 63,000 people in more than 106 countries were able to report their situation to those exported for trade from 2014 to 2018. These figures only roughly reflect the scale of this type of forced irregular migration.

It is worth noting that a significant share in trafficking in persons is made up of women and children, who often cannot, due to external circumstances, report their plight. In this connection, UN experts suggest that the proportion of victims of this type of migration is much higher. According to experts, forced migration does not always involve the use of state coercion. A certain policy can also «force» migration, creating unbearable conditions for the life of a social group within a given territory. Forced migrations can be called the movement of large numbers of people traveling not by their own will, but by virtue of coercion by the state, direct or indirect. The first type is defined as deportation; the second is voluntary forced migration. Its fundamental difference is that the state «influences» the circumstances and factors of individual decision-making on resettlement. The type of migration to which the term «deportation» is applied is also found as «repressive migration». Repressive migrations are a direct consequence of the certain mechanisms of a totalitarian or authoritarian regime, the mechanisms of which involve the use of repression as a way of forming the normative behavior of an individual in the given society. In addition, repressive types of migration are directly related to the needs of the state economy. The relocation of a large number of people from one region to another can stimulate the economic development of the host territory with minimal financial costs. A number of characteristic features of deportation as a type of forced migration can be distinguished: they are administrative, extra-judicial; repressions are aimed at a whole group of people, sometimes very numerous; decisions on repressions are usually made by party and government leaders.

Another direction of the classification of the second rate migrations is the allocation of migrations depending on plans for the final destination. Here, the previously mentioned pendulum migrations and vector migrations are distinguished. Pendulum migrations suggest the presence of the so-called «oscillation period», that is the endpoint of migration in this embodiment, in fact, does not exist. There are only time intervals that the individual spends on staying between two spatial points, socially equidistant from him. It is a question of social distance in this case, since pendulum migration is tied not so much to geographical, physical distance, but to the distance between two social positions located in different geographical locations. The individual makes movements, trying to maintain both social positions, returning alternately to one, then to the other. This is the fundamental difference between pendulum migrations and vector migrations. Vector migrations do not imply a constant return from one point to another. The endpoint in this variant of migration exists, but, as the authors of this typology note, it becomes finite for individuals for different periods of time, that is not only the spatial factor is involved, but also the temporal one.

Accordingly, we can single out: constant vector migrations, which suggest a final «gap» 
between the starting point of migration and the final; permanent-temporary migrations associated with moving to the final point of migration for a certain period of time, followed by returning to the starting position; temporary (one-time) migrations, these include tourism, travel.

An important criterion for typologizing migration is the criterion of administrative boundaries. Depending on this factor migrations are divided into internal and external. Internal ones are divided into intra-regional and inter-regional. External ones, in their turn, are guided by «entry» and «exit»: emigration and immigration. In the framework of external migration, they distinguish between transit (with double crossing of the state border) and border (frontier, reflecting the depth of penetration into the internal territories - how far it is from the administrative border). According to the authors, this typology becomes relevant when analyzing the concept of national states, when the issue of territorial delimitation is practical and of marking nature. At the moment, typologization of migration on the basis of sociocultural boundaries seems relevant. This typology is based on the theory of sociocultural systems, according to which social and cultural formations are formed in the migrant's mind, which are perceived by the individual as «their own» space, and alien socio-cultural formations. Considering the classifications and typologies of migrations, it should be noted that in the present-day world, migrations can also be divided into individual, group, and mass according to the degree of intensity. In modern society, thanks to the development of mass communications, means of communication, etc. the so-called «global village» is formed, where individuals can make movements, focusing on their beliefs, motives and goals, rather than a group decision. If, until a certain point, an individual could not afford to weaken collective ties, then today, with the intensification of individualization processes, these bonds cease to play a key determining role in choosing the final point of movement.

Conclusions. The above attempt to systematize the previous typological experience of migration processes nevertheless demonstrates some staticity. In existing approaches, new types and forms of migrations related to globalization of the world community and the development of information technologies are not practically integrated. The transformation of the world community and technological progress causes regular changes in the processes associated with the movement of individuals in the social space. We are talking about virtual migrations, the accounting of which is less relevant for government statistics services (this issue is not reflected or considered in any way in the UN recommendations on accounting for migrations), however, from the perspective of analyzing the changes in the entire socium, this category of migrations is no less important - it transforms the vision of its social space, the perception of culture and value systems, changes the usual boundaries of social space.

Thus, the methods of classifying migration that have been developed over a long period of time, expressed in traditional terms of the policies of national states, lose their former research power, giving way to transnational dimensions. There appear new migration criteria legal / illegal, seasonal / pendulum, voluntarily compelled (refugees and immigrants), indicating the danger to a person of losing his national identity.

\section{References:}

1. Доклад о человеческом развитии 2016: Человеческое развитие для всех и каждого // Опубликовано для Программы развития Организации Объединенных Наций (ПРОOH). URL : http://www.un.org/ru/index.html.

2. Международная миграция и развитие: Доклад Генерального секретаря ООН. // Генеральная ассамблея, 4 августа $2016 . \quad$ URL http://www.un.org/en/development/desa/population/migration/generalassembly/docs/A_71_296_R.pdf.

3. Is migration good for the economy? Migration Policy Debates. OECD. May $201 \overline{4}$. URL : http://www.oecd.org/els/mig/migration-policy-debates.htm.

4. Meer N., Modood T. Cosmopolitanism and integationism: is British multiculturalism a «zombie category». Identities: global studies in culture and power. 2014. Mar. 21. P. 1-17.

Received to editorial office 02.12.2019

1. Doklad o chelovecheskom razvitii 2016: Chelovecheskoye razvitiye dlya vsekh i kazhdogo [Human Development Report 2016: Human Development for Everyone and Everyone] // Opublikovano dlya Programmy razvitiya Organizatsii Ob"yedinennykh Natsiy (PROON). URL : http://www.un.org/ru/index.html. [in Russ.]

2. Mezhdunarodnaya migratsiya i razvitiye [International Migration and Development]: Doklad General'nogo sekretarya OON. // General'naya assambleya, 4 avgusta 2016. URL : http://www.un.org/en/development/desa/population/migration/generalassembly/docs/A 71296 R.pdf. [in Russ.]

3. Is migration good for the economy? Migration Policy Debates. OECD. May 2014. URL : http://www.oecd.org/els/mig/migration-policy-debates.htm. [in Eng.]

4. Meer, N., Modood, T. (2014) Cosmopolitanism and integationism: is British multiculturalism a «zombie category». Identities: global studies in culture and power. Mar. 21. P. 1-17. [in Eng.] 


\section{Summary}

Methods of classifying migration, expressed in the traditional forms of migration policy of states, have been formed over a long period and are losing their former research weight, giving way to transnational dimensions.

Given the urgency of this issue, the authors of the article attempt to systematize the existing experience of typing migration and to offer a unified approach to the use of a specific typology to provide legal protection for this category of population.

Keywords: migration, typology, systematization, criterion, protection, rights and freedoms.

UDC 342.95

DOI: $10.31733 / 2078-3566-2019-5-122-127$

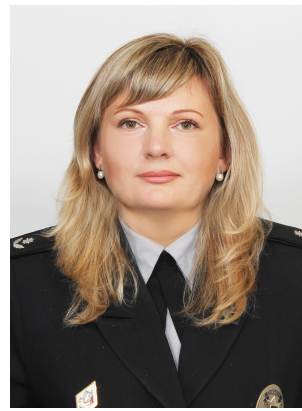

Svitlana RYZHKOVA ${ }^{\circledR}$

inspector

(the Main Department of the National Police

in Dnipropetrovsk region)

\section{STATE MIGRATION SERVICE OF UKRAINE AS AN ACTOR OF ANTI-ILLEGAL MIGRATION}

Світлана РИжкова. ДЕРЖАВНА МІГРАЦІЙНА СЛУЖБА ЯК СУБ’ЄКТ ПРОТИДІї

НЕЛЕГАЛЬНІЙ МІГРАЦІЇ. У статті розглянуто організаційно-правові аспекти діяльності Державної міграційної служби як суб'єкта протидії нелегальній міграції, та визначено основні чинники, які гальмують даний напрям. Також надані пропозиції щодо удосконалення такої діяльності.

Наголошується, що незаконна (нелегальна) міграція є одним 3 явищ, що сформувалася за часів розбудови незалежної України та становить загрозу суспільній і національній безпеці, економічній стабільності, спричинює ускладнення криміногенної ситуації на території України i серйозно впливає на стан економіки та законності. Чинником, що завжди супроводжує нелегальну міграцію, є вчинення іноземцями та особами без громадянства адміністративних правопорушень на території держави їх перебування.

Приділяється увага питанням протидії нелегальної міграції, вивченням правового регулювання суспільних відносин у сфері міграції, визначенням причин і наслідків, та способів запобігання нелегальній міграції. Також означені сучасні аспекти протидії нелегальній міграції органами державної міграційної служби в контексті міграційних ризиків, законодавчих та організаційно-правових змін в Державної міграційної служби.

Вказується, що Державна міграційна служба відповідно до покладених на неї завдань здійснює заходи щодо запобігання та протидії нелегальній (незаконній) міграції, іншим порушенням міграційного законодавства, виконує в межах повноважень, передбачених законом, правозастосовні і правоохоронні функції.

В процесі дослідження аргументується твердження про те, що незаконне перебування іноземців в Україні перетворилося на вагомий дестабілізуючий фактор у сфері забезпечення публічного порядку та безпеки. Саме 3 незаконною міграцією пов'язується зростання окремих видів правопорушень на території України.

Констатується, що відсутність інформаційної бази даних про іноземців, визнаних нелегальними мігрантами, збільшує терміни їх ідентифікації i унеможливлює оперативне здійснення працівникам територіальних органів і установ Державної міграційної служби перевірки затриманих осіб щодо повторності вчинення ними правопорушень, застосування підвищених розмірів адміністративних штрафів або інших заходів міграційного впливу.

Ключові слова: державна міграчійна служба, нелегальна міграція, мігрант, іноземеиь, особа без громадянства.

Problem statement. Ukraine is a full member of the international community on the international stage. At the same time, with the years of independence, processes related to the establishment of good neighborly relations with neighboring states, integration and strategic partnership have become increasingly important. Thus, one of the key vectors in the foreign policy of our country is the direction for the integration of Ukraine into the European Union, other interna-

(C) Ryzhkova S., 2019

ORCID iD: https://orcid.org/0000-0002-5044-6866

revord@gmail.com 